\title{
NUTRITIONAL HEART DISEASE
}

BY

\author{
A. D. GILLANDERS \\ From the Baragwanath Hospital, Johannesburg, S. Africa
}

Received January 9, 1950

The prevailing concept of beri-beri heart disease is based on the syndrome described by Alsmeer and Wenckebach (Wenckebach, 1928, 1932, 1934; Alsmeer and Wenckebach, 1929). It was heart failure characterized by sinus rhythm, systemic venous engorgement, peripheral œdema, and signs of a fast circulation such as bounding pulses and pistol-shot sounds over the major arteries. They emphasized that the failure was exclusively of the right heart. The electrocardiogram was normal except for a " certain degree of preponderance of the right ventricle." Enlargement of the heart was progressive, but whereas in the earliest phase of the disease this involved the whole heart, subsequent enlargement chiefly affected the right side. Histologically, the salient lesion was " hydropic" degeneration of the myocardium. Wenckebach attributed the whole syndrome to water retention. He regarded the functional defect of the myocardium as one of contractility, conduction being unimpaired. The disease was endemic in the Dutch East Indies.

Weiss and Wilkins $(1936,1937)$ reported a high incidence of "beri-beri heart" among chronic alcoholics in America. The disease that they described, however, differed considerably from oriental beri-beri. Some of their patients did have a hyperkinetic circulation and dominant failure of the right heart but still more "with an identical type of deficiency showed pulmonary engorgement with dyspnœa, cardiac asthma, orthopnœa, and other manifestations of left-sided failure." They remarked that although vitamin $\mathbf{B}_{1}$ deficiency was principally the cause of alcoholic beri-beri as of the oriental variety, the response to treatment with the vitamin was not uniform. The most striking thing about the subsequent reports on the cardiac form of beri-beri is the variability of the disease that is described under this name. Only rarely does it conform to the criteria of Alsmeer. and Wenckebach and recently the trend has been to deny any specificity to the syndrome (Dock, 1940; Hussey and Katz, 1942; Vilter, 1945. Blankenhorn, 1945). Failure to respond to aneurin in adequate dosage is not regarded as compromising the diagnosis (Hussey and Katz, 1942; Blankenhorn, 1945).

The purpose of this paper is to describe a form of heart disease that is thought to be caused by malnutrition. It is not the same disease as that described by Alsmeer and Wenckebach. It is unaffected by aneurin and will not, for these reasons, be referred to as beri-beri. It has the further characteristic of being invariably associated with progressive liver disease of a kind that is known to be caused by malnutrition (Gillman and Gillman, 1945).

\section{Clinical Material}

The following account is based on 30 Bantu patients with heart failure of this kind who have been observed during the past eighteen months. Of the thirty, 22 were men and 8 women; the youngest was aged 30 and the oldest 63 years. It is necessary to emphasize that these figures have no significance other than that the disease is not a rare one in the urban Bantu community from which these patients were drawn. Certainly the disease occurs in childhood. 


\section{DiETETIC HISTORY}

The diet of all patients consisted of porridge made from highly refined maize, supplemented with white bread, tea, and sugar. Meat and milk were consumed in very small quantity or not at all, and only rarely were vegetables or fruit added. This, indeed, is the staple diet of the Bantu community in urban areas (Phillips, 1938; Fox, 1941). The scale of nutrition is set by low wages which, under ideal domestic budgeting, are not sufficient to provide the nutritional requirements for a minimum standard of health (Blair, 1947). Added to this, perhaps not unnaturally, is ignorance of the nutritive value of the various foods that are for sale in the towns.

\section{Clinical Features}

The ultimate disablement of most patients is caused by dropsical swelling of the whole body. It begins in the feet and spreads upwards to involve the trunk, upper limbs, and face. Twenty-six patients described their dominant symptom in this way. All had dyspnœa on effort but only three referred to this symptom before all others; none had had paroxysmal nocturnal dyspnœa or effort pain. One patient sought medical advice primarily on account of neuritic symptoms although he had heart failure at the same time. Additionally, twelve patients complained of a dry cough and sixteen of pain in the right upper quadrant of the abdomen. Of the eight women three were past the menopause, four had amenorrhøea, and one menstruated regularly.

Duration of symptoms. The South African Bantu has a singularly negative attitude to time and for that reason (and others) it is difficult to discover the precise duration of the symptoms complained of. Among those who were in hospital for the first time the reputedly longest duration of symptoms was four weeks, the shortest three days. It may be said with reasonable certainty that in contrast to the extreme signs of disease the duration of symptoms is surprisingly brief. Nineteen had previously been in hospital on account of heart failure, eight on more than one occasion and one as often as eight times. Of these the longest period between successive admissions was four months, the shortest two weeks.

Signs. The most striking feature of all patients with a single exception was odema of extreme degree. In distribution it was generalized, although maximum in the lower parts of the body. The neck veins were engorged and the brachial venous pressure high (Table II). Chemosis was obvious in most patients; three had subconjunctival hæmorrhages. Six had proptosis, interpreted as due to venous engorgement within the orbit, but none had either papillœdema or retinal hæmorrhages. Twenty-seven of the thirty patients had clinically recognizable ascites; in twenty-three of these the abdomen was tensely distended. Thirteen had hydrarthrosis of both knees and six had bilateral hydrocele. In contrast, only seven patients had hydrothorax. This was bilateral in three instances; in the remainder the right and left sides were equally involved. The estimated protein content of œdema fluid from various sources is shown in Table I. The liver was invariably enlarged and, initially, tender. Crepitations were heard over the basal parts of the lungs in twenty-five patients.

TABLE I

Percentage Protein Content of Cedema fluid

\begin{tabular}{|c|c|c|c|c|c|c|}
\hline & & Subcutaneous & Ascitic & Pleural & Hydrocele & Joint \\
\hline $\begin{array}{lll}\text { Range } & \ldots & \ldots \\
\text { Mean } & \ldots & \ldots \\
\text { Number of } & \text { patients }\end{array}$ & $\begin{array}{l}\ldots \\
\cdots \\
\cdots\end{array}$ & $\begin{array}{c}0.05-0.60 \\
0.2 \\
10\end{array}$ & $\begin{array}{c}2 \cdot 0-6.0 \\
3.6 \\
6\end{array}$ & $\begin{array}{c}1 \cdot 2-4 \cdot 0 \\
2 \cdot 8 \\
6\end{array}$ & $\begin{array}{c}2 \cdot 4-5 \cdot 0 \\
3.9 \\
5\end{array}$ & $\begin{array}{c}2 \cdot 0-3 \cdot 2 \\
2 \cdot 7 \\
4\end{array}$ \\
\hline
\end{tabular}

Almost all patients when admitted to hospital preferred to sit up supported, rather than to lie recumbent. Two patients adopted the knee-elbow position by choice; they slept in this position. In darkly pigmented people the presence or absence of cyanosis is too difficult to assess to be a reliable sign. The hands of most were regarded as being cold; strikingly warm hands were never 
observed notwithstanding that six patients had mild fever during the first few days that they were in hospital. Arterial pulses were of small volume, never bounding; pistol-shot sounds were not heard in these patients.

TABLE II

Heart Rate, Venous Pressure, and Circulation times Prior to any form of Treatment

\begin{tabular}{|c|c|c|c|c|c|}
\hline & $\begin{array}{l}\text { Heart rate per } \\
\text { minute }\end{array}$ & $\begin{array}{l}\text { Brachipl venous } \\
\text { pressure, mm. } \\
\text { saline above } \\
\text { sternal angle * }\end{array}$ & $\begin{array}{l}\text { Arm to tongue } \\
\text { time, seconds }\end{array}$ & $\begin{array}{l}\text { Arm to lung } \\
\text { time, seconds }\end{array}$ & $\begin{array}{l}\text { Lung to tongue } \\
\text { time, seconds }\end{array}$ \\
\hline $\begin{array}{ll}\text { Range } & .\end{array}$ & $\begin{array}{c}72-120 \\
94 \\
12 \cdot 8 \\
30\end{array}$ & $\begin{array}{c}85-350 \\
220 \\
87 \cdot 1 \\
19\end{array}$ & $\begin{array}{c}15 \cdot 0-84 \cdot 0 \\
39 \cdot 8 \\
19 \cdot 2 \\
27\end{array}$ & $\begin{array}{c}6 \cdot 0-46 \cdot 0 \\
22 \cdot 7 \\
11 \cdot 1 \\
24\end{array}$ & $\begin{array}{c}5 \cdot 0-47 \cdot 0 \\
15 \cdot 7 \\
9 \cdot 1 \\
24\end{array}$ \\
\hline
\end{tabular}

* Patient supported in position of 45-degrees recumbency.

The heart was enlarged in all. Its size and shape will be referred to in detail below. The cardiac impulse was feeble or, more commonly, impalpable. Heart rates at the time of admission to hospital ranged from 72 to 120 (Table II). Sinus rhythm was invariable. All had a diastolic gallop. In twelve instances the gallop was thought to be presystolic in type and in six protodiastolic; in the remainder the rate was too fast for the extra heart sound to be timed more accurately by auscultation alone. Two patients had infrequent ventricular extrasystoles. Sixteen had a systolic murmur, heard maximally at the apex. The highest systolic pressure recorded at the time of admission to hospital was 152 , the lowest 90 . Corresponding maximum and minimum diastolic pressures were 90 and 70. Pulse pressures varied from 16 to 62 (Table III). In two patients pulsus alternans was perceptible at the wrist; in ten others there was alternation in the upper 10 to $15 \mathrm{~mm}$. of the systolic pressure scale. This sign was not constantly recorded; if it had been it is probable that its frequency would have been higher. Mean circulation times were prolonged over arm to lung and lung to tongue segments (Table II). In individual patients lung to tongue time was a reasonable measure of pulmonary congestion.

TABLE III

Blood Pressure during Period in Hospital

\begin{tabular}{|c|c|c|c|c|c|c|c|c|c|}
\hline & & & \multicolumn{3}{|c|}{ On admission } & \multicolumn{2}{|c|}{$\begin{array}{l}\text { Maximum recorded } \\
\text { in course of } \\
\text { clinical improvement }\end{array}$} & \multicolumn{2}{|c|}{ On discharge } \\
\hline & & & Systolic & Diastolic & $\begin{array}{c}\text { Pulse } \\
\text { Pressure }\end{array}$ & Systolic & Diastolic & Systolic & Diastolic \\
\hline 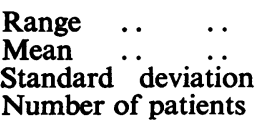 & $\begin{array}{l}\cdots \\
\cdots \\
\cdots\end{array}$ & $\begin{array}{l}\cdots \\
\cdots \\
\cdots\end{array}$ & $\begin{array}{l}90-152 \\
122 \\
17 \cdot 8 \\
30\end{array}$ & $\begin{array}{c}70-90 \\
83 \\
7 \cdot 7 \\
30\end{array}$ & $\begin{array}{c}16-62 \\
39 \\
14 \cdot 5 \\
30\end{array}$ & $\begin{array}{c}105-156 \\
133 \\
14 \cdot 8 \\
21\end{array}$ & $\begin{array}{c}80-108 \\
95 \\
6 \cdot 2 \\
21\end{array}$ & $\begin{array}{c}104-140 \\
119 \\
11 \cdot 2 \\
21\end{array}$ & $\begin{array}{l}70-90 \\
79 \\
5 \cdot 0 \\
21\end{array}$ \\
\hline
\end{tabular}

Most patients had some albumen in the urine but no significant microscopic content. Glycosuria was excluded by routine examination. The test for ketone bodies was not always done (because its significance was not originally realized) but certainly some patients had ketonuria. The eye grounds of all were normal apart from engorgement of veins. None had primary lung disease by clinical and radiological standards. Ova of Ascaris lumbricoides were found in the fæces 
of six patients. There was no evidence of chronic malaria, bilharziasis, or other parasitic infection in any. Twenty-one patients had signs of peripheral neuritis. One of these had quadriparesis. The remainder had little apparent loss of motor power but in all the knee or ankle jerks, or both, were absent. It was estimated that ten of these had depressed sensation in the distal parts of the lower limbs.

Seven patients had a pellagrous dermatosis. None complained of a sore tongue and none had stomatitis or diarrhœa. In three patients there was a minor abnormality of the tongue; it was a little reddened and raw at its margins but in no instance closely resembled the kind that has been attributed to deficiency of various components of the vitamin B complex. In the African, testicular atrophy, gynæcomastia, and parotid gland enlargement are reputed to be consequences of malnutrition (Davies, 1948, 1949). It is difficult to recognize minor degrees of testicular atrophy but this sign was recorded in fourteen patients. Sixteen had gynæcomastia. Paratosis was observed in one instance only.

\section{LABORATORY INVESTIGATIONS}

The results of these investigations are shown in Tables IV and V. Quantitative tests of this kind and, indeed, all quantitative tests must be interpreted with caution for there is little knowledge

TABLE IV

Alteration of Plasma Protein Percentage During Treatment

\begin{tabular}{|c|c|c|c|c|c|c|c|c|}
\hline & & & \multicolumn{3}{|c|}{ On admission } & \multicolumn{3}{|c|}{ On discharge } \\
\hline & & & $\begin{array}{c}\text { Total } \\
\text { protein, } \\
\text { g. per cent. }\end{array}$ & $\begin{array}{l}\text { Albumen, } \\
\text { g. per cent. }\end{array}$ & $\begin{array}{l}\text { Globulin, } \\
\text { g. per cent. }\end{array}$ & $\begin{array}{c}\text { Total } \\
\text { protein, } \\
\text { g. per cent. }\end{array}$ & $\begin{array}{l}\text { Albumen, } \\
\text { g. per cent. }\end{array}$ & $\begin{array}{l}\text { Globulin, } \\
\text { g. per cent. }\end{array}$ \\
\hline $\begin{array}{l}\text { Range } . . \\
\text { Mean } . . \\
\text { Standard deviation } \\
\text { Number of patients }\end{array}$ & $\begin{array}{l}\ldots \\
\cdots \\
\cdots \\
\cdots\end{array}$ & $\begin{array}{l}\cdots \\
\cdots \\
\cdots\end{array}$ & $\begin{array}{c}4 \cdot 5-8 \cdot 5 \\
6 \cdot 1 \\
1 \cdot 0 \\
30\end{array}$ & $\begin{array}{c}2 \cdot 4-5 \cdot 2 \\
3 \cdot 4 \\
0 \cdot 7 \\
30\end{array}$ & $\begin{array}{c}1 \cdot 4-4 \cdot 2 \\
2 \cdot 7 \\
0 \cdot 6 \\
30\end{array}$ & $\begin{array}{c}5 \cdot 4-9 \cdot 7 \\
7 \cdot 1 \\
1 \cdot 2 \\
20\end{array}$ & $\begin{array}{c}3 \cdot 0-4 \cdot 9 \\
4 \cdot 0 \\
0 \cdot 5 \\
20\end{array}$ & $\begin{array}{c}2 \cdot 1-5 \cdot 4 \\
3 \cdot 1 \\
0 \cdot 9 \\
20\end{array}$ \\
\hline
\end{tabular}

of physiological values in the Bantu. Relative to normal values in other communities (Moore and Van Slyke, 1930; Trevorrow, et. al., 1941) plasma albumen levels are low and globulin levels high. In the individual patient, however, plasma albumen concentration did not correlate with the amount of cdema, nor with the severity of the disease by any other clinical standard. The increase in plasma globulin did appear to bear a direct relation to the degree of liver injury as estimated by biopsy or post-mortem examination.

Serum sodium and potassium do not differ from reported normal values (Harrison, 1947; Cecil, 1947). The mean plasma cholesterol level is low although a wide scatter is revealed. More significant perhaps is the range of fasting blood sugar which is almost certainly on a lower scale

TABLE V

Biochemical Investigations of Blood and Serum

\begin{tabular}{|c|c|c|c|c|c|c|c|c|}
\hline & & & $\begin{array}{c}\text { Serum } \\
\text { potassium, } \\
\text { mg. per cent. }\end{array}$ & $\begin{array}{c}\text { Serum } \\
\text { sodium, } \\
\text { mg. per cent. }\end{array}$ & $\begin{array}{c}\text { Plasma } \\
\text { cholesterol, } \\
\text { mg. per cent. }\end{array}$ & $\begin{array}{c}\text { Blood } \\
\text { urea, } \\
\text { mg. per cent. }\end{array}$ & $\begin{array}{l}\text { Fasting } \\
\text { venous } \\
\text { blood sugar, } \\
\text { mg. per cent. }\end{array}$ & $\begin{array}{c}\text { Hb., } \\
\text { g. per cent. }\end{array}$ \\
\hline $\begin{array}{l}\text { Range } \ldots \\
\text { Mean } . . \\
\text { Standard deviation } \\
\text { Number of patients }\end{array}$ & $\begin{array}{l}\cdots \\
\cdots \\
\cdots\end{array}$ & $\begin{array}{l}\cdots \\
\cdots \\
\cdots\end{array}$ & $\begin{array}{c}16-24 \\
19 \cdot 6 \\
1 \cdot 5 \\
22\end{array}$ & $\begin{array}{c}308-362 \\
333 \cdot 6 \\
14 \cdot 0 \\
23\end{array}$ & $\begin{array}{c}80-260 \\
113 \cdot 6 \\
41 \cdot 6 \\
23\end{array}$ & $\begin{array}{c}16-60 \\
34 \cdot 4 \\
11 \cdot 7 \\
23\end{array}$ & $\begin{array}{l}60-97 \\
77 \cdot 5 \\
12 \cdot 0 \\
21\end{array}$ & $\begin{array}{c}12 \cdot 9-19 \cdot 5 \\
16 \cdot 0 \\
1 \cdot 6 \\
22\end{array}$ \\
\hline
\end{tabular}


than the normal in the same race. The mean hæmoglobin value in healthy European adult men at the altitude of this city is 17.8 grams., in women 15.3 grams per $100 \mathrm{ml}$. (Lurie, 1949). The mean for both sexes is not significantly different from that in the patients now under consideration. Where blood urea was raised this was a pre-renal effect. Among those who survived there was no recognizable impairment of renal function after recovery from heart failure, and of those that died none had renal disease.

\section{RADIOLOGICAL EXAMINATION}

The heart was enlarged in all, in most instances grossly so. Invariably the enlargement affected both sides of the heart. In proportion to the degree of enlargement the heart became globular in outline. The middle arc of the left cardiac border was inconspicuous. The appearance of the aortic arch was not abnormal. The amplitude of cardiac (and aortic) pulsation was minimal and this applied irrespective of the degree of enlargement and of rate in the untreated patient. Congestive changes in the lung fields or engorgement of the pulmonary veins were observed in twenty-seven patients; in the remainder the lung fields were strikingly clear (Fig. 9). As already mentioned, three had bilateral, and four unilateral hydrothorax.

The enlarged, globular, inert heart is fluoroscopically characteristic, although not necessarily pathognomonic. It resembles the type of heart that is attributed to myxodema, a diagnosis that was rigidly excluded by other standards. Nevertheless, the differential diagnosis from pericardial effusion was at times questioned, and in twelve patients the pericardium was needled on one or more occasions but never was it possible to aspirate fluid. This corresponded to post-mortem findings. Illustrative teleradiograms are shown in Fig. 1, 2, 4, 5, 7; 8 and 9.

\section{The ELECTROCARDIOGRAM}

Twenty patients were examined by standard and unipolar leads. Of these, by cardiographic standards (Bain and Redfern, 1948), eleven had left ventricular hypertrophy with a horizontal or semi-horizontal position of the heart; three had the pattern of left ventricular hypertrophy in præcordial leads but with a vertical heart in each instance, presumably implying hypertrophy of both ventricles. One had right ventricular hypertrophy with a vertical axis and two had right bundle branch block. In the remaining three neither ventricle was cardiographically dominant. These patterns were preserved throughout the course of the illness and did not alter with recovery. The most constant feature of the electrocardiogram was a curve of subepicardial injury and this was observed in twelve patients (Fig. 3 and 6). In these the electrocardiogram did not usually become stabilized in less than ten weeks. The P-R interval was prolonged beyond 0.2 second in one patient; he also had right bundle branch block. Of the twenty patients ten had low voltage QRS complexes in unipolar limb leads (Goldberger, 1947).

Ten patients were examined by standard limb leads and two or more bipolar chest leads. For technical reasons some of these records were unsatisfactory and in most instances only a single cardiogram was available. Of the ten, five had low voltage QRS complexes, four had left axis deviation, and two right axis deviation. $\mathrm{T} 1$ or $\mathrm{T} 1$ and $\mathrm{T} 2$ were inverted or isoelectric in seven patients. The P-R interval was prolonged in none. All had sinus rhythm; two had ventricular extrasystoles.

\section{Etiological Diagnosis}

It was obvious from the time when this disease was first encountered that it did not conform to any of the common categories of congestive heart failure. The preliminary stages of establishing an atiological diagnosis preceded the planned investigation that forms the basis of this paper. Clinically the dynamic quality of the circulation indicated that the cardiac output was low. It was argued for that reason that digitalis would not be harmful. It transpired that it was not helpful-at least not in these early cases that were admittedly severe. 
Notwithstanding the dissimilarity from beri-beri heart failure the known inadequacy of the patients' diet (including deficiency of vitamin $\mathbf{B}_{1}$ ) made consideration of this diagnosis imperative. Accordingly treatment with intravenous thiamin in dosage varying from 50 to $150 \mathrm{mg}$. daily was tried. At the same time the patients were confined to bed in hospital and given a well-balanced diet. No attempt was made to restrict the intake of sodium chloride. None of the dramatic recoveries reported in beri-beri occurred, but over a period of 7 to 10 days some patients improved greatly. In these, after two to three weeks, odema had disappeared and heart size had become much smaller. It was then decided to try the effect of the same diet without added thiamin. Precisely the same favourable result occurred in the same proportion of patients and in as short a time. It was at this stage that the present investigation began.

Five patients in moderately severe failure, on being admitted to hospital, were confined to bed and given a diet similar, so far as was possible from the information they gave, to their accustomed diet at home. This consisted of porridge made from refined maize, half a pint of milk daily, tea, sugar, white bread, and jam. The quantity of milk only was controlled. Without exception their clinical condition deteriorated; they gained weight and œdema became more pronounced; heart size increased further (Fig. 1). There is obviously a limit to which this type of observation can be pursued but it is justified because present circumstances make it inevitable that these patients will revert to the same diet as soon as they leave hospital. After not more than two weeks on this restricted diet the patients were given the standard diet already referred to. In one to three weeks time œdema disappeared and distension of neck veins ceased to be apparent in all. In two of the five heart size returned to normal (Fig. 1); in the remainder it diminished considerably but failed to revert to normal. This residual enlargement, which will be discussed below, did not yield to any subsequent treatment. The remaining 25 patients were placed on an optimum diet from the time of their admission to hospital. Seven of these made a complete recovery in so far as all œdema disappeared, venous pressure fell to normal (as judged by the absence of distension of cervical veins) and enlargement of the heart was no longer apparent (Fig. 2 and 4). This favourable result occurred in less than four weeks in all, and with no other treatment than wholesome food. At that stage six of these patients, while still confined to bed, had their diet restricted as in the previous group but supplemented as follows: two were given $25 \mathrm{mg}$. of aneurin, two were given 10 grams of brewers' yeast, and two were given $500 \mathrm{mg}$. of alpha-tocopherol acetate each day (the rationale of this and other therapeutic trials will be discussed subsequently). The longest period over which this controlled diet was continued in any instance was three weeks. An enlarging heart, an increase in peripheral venous pressure, and a recurrence of œdema was apparent in all (Fig. 2, 4 and 5). These changes were reversed when the original diet was resumed. The basic pattern of the electrocardiogram was not noticeably influenced by restriction of diet over this brief period.

It follows from what has been stated that nine patients made an apparently complete recovery from heart failure on dietetic treatment alone (their recovery was not complete in other respects). Thirteen patients made a partial recovery on the same treatment. In these, when maximum improvement had been obtained by this means, dietetic treatment was supplemented in one or more of the following ways:

(a) Thirteen patients were given $2 \mathrm{ml}$. of mersalyl intramuscularly every other day or twice weekly for periods ranging from 3 weeks to 3 months. In eight of these the drug caused an increased urinary excretion and weight loss varying from 1.3 to $4.5 \mathrm{~kg}$., but further benefit was not forthcoming and in no instance was the ædema dispelled. No perceptible effect on heart size or circulatory efficiency was observed in any.

(b) Ten patients were given digitalis. No sustained improvement in the circulation followed. There was no change in heart size nor was there significant weight loss in any patient.

(c) The combination of digitalis and mersalyl was tried in eight patients. The effect was not apparently better than that due to mersalyl alone.

(d) Ten patients were given 50 to $200 \mathrm{mg}$. of aneurin daily for periods varying from 10 to 20 days. No beneficial effect was observed. 

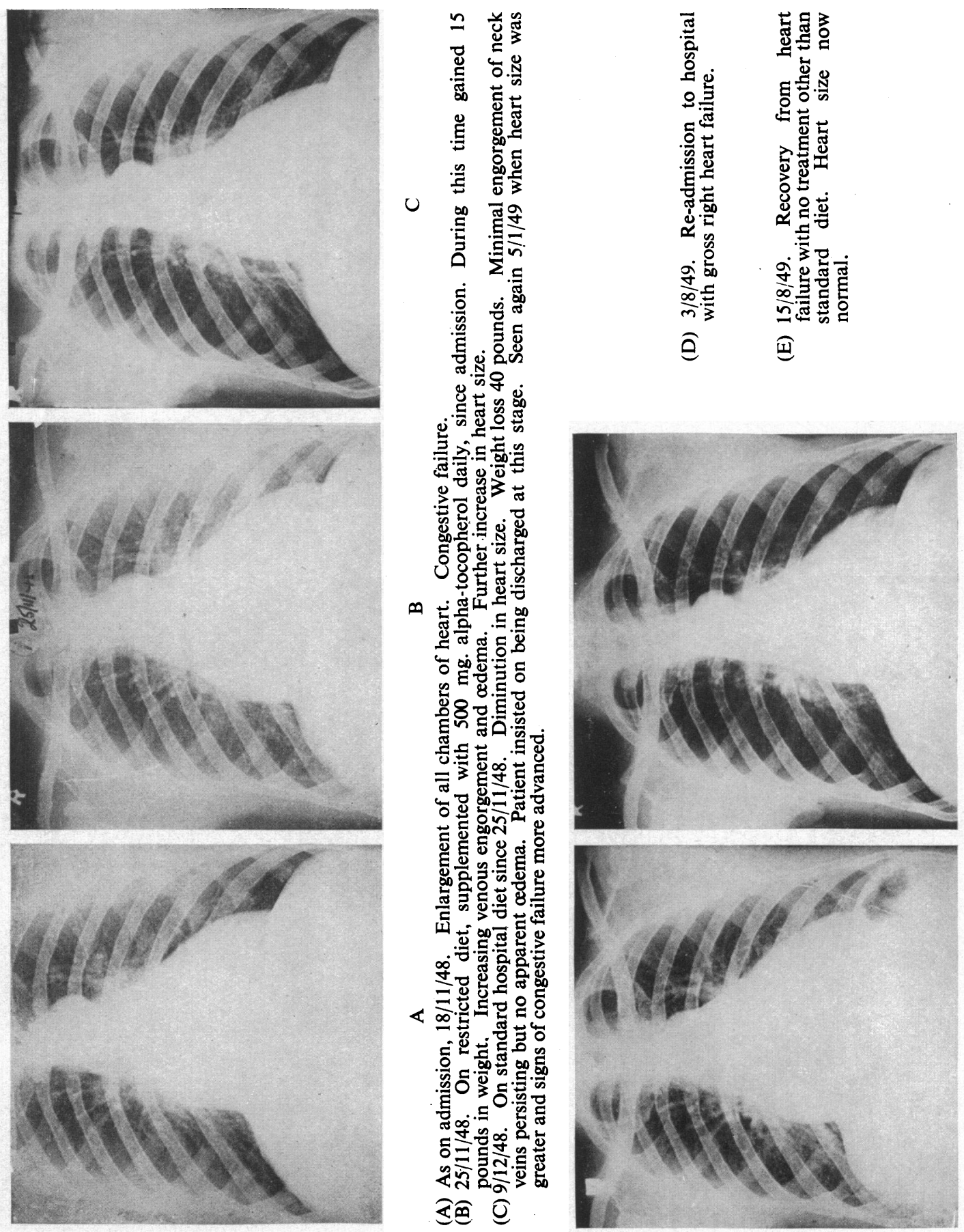

山

Fig. 1.*-Man, aged 34 (Reference No. 16434/48).

* These and subsequent reproductions are of 6-ft. teleradiograms. 


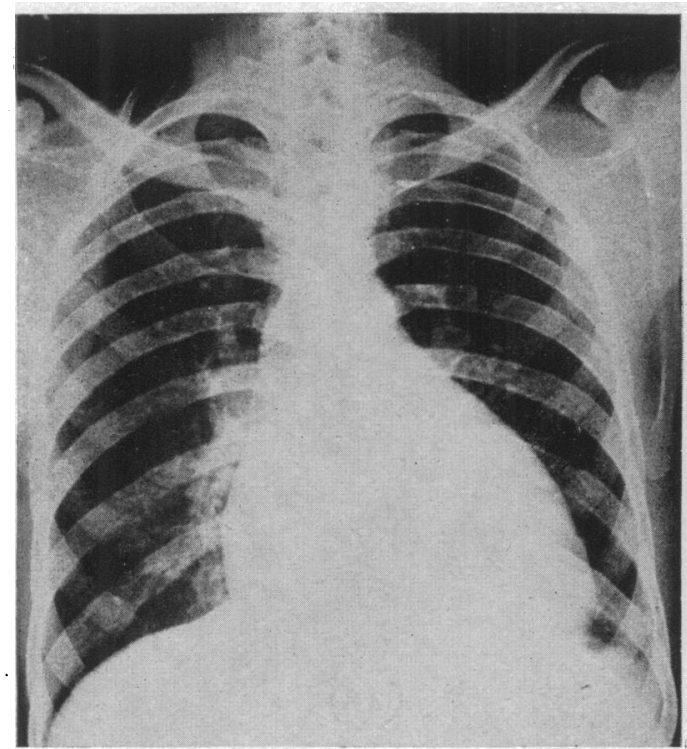

A

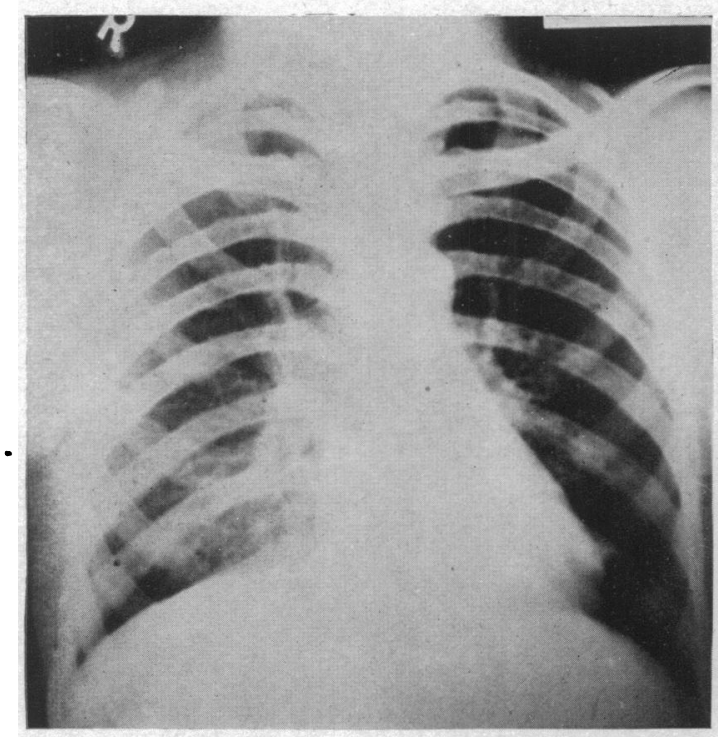

C

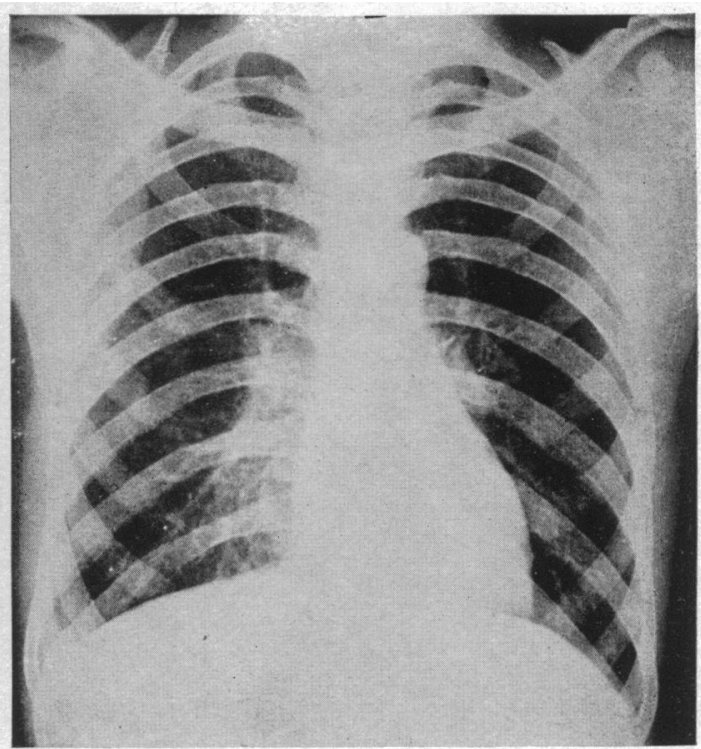

B

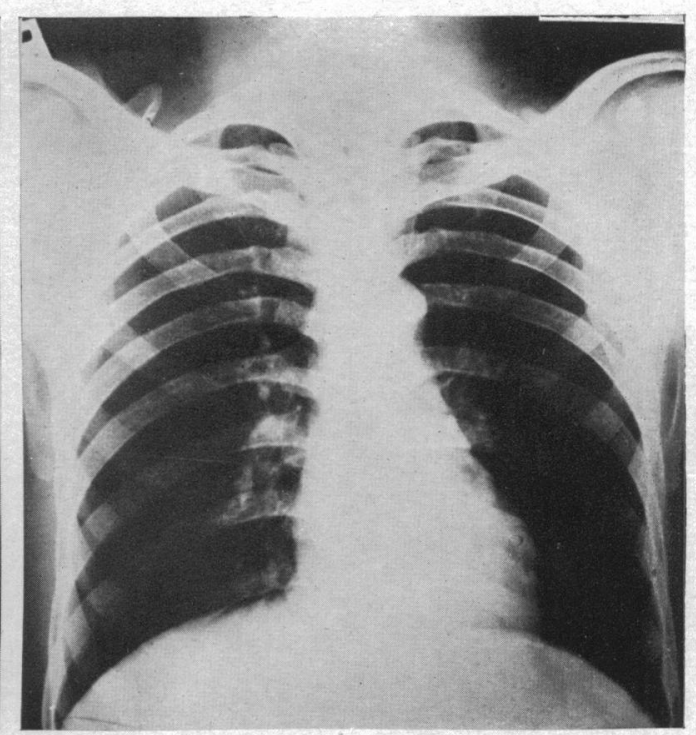

$\mathrm{D}$

Fig. 2.-Man, aged 30 (Reference No. A12681).

(A) As on admission, 5/4/49. Enlargement of all chambers of heart. Congestive failure.

(B) 3/5/49. Patient has received no treatment other than standard hospital diet. Heart size now normal. Systemic veins no longer engorged. No œema. Weight loss 52 pounds.

(C) $12 / 5 / 49$. On restricted diet, supplemented with $25 \mathrm{mg}$. aneurin daily, since 3/5/49. Teleradiogram shows increase in heart size. Neck veins again distended; œdema over sacrum.

(D) $26 / 5 / 49$. Resumed standard diet on 12/5/49. Heart size normal. Recovery from congestive failure. No supplementary treatment of any kind.

Corresponding electrocardiograms are shown in Fig. 3. 


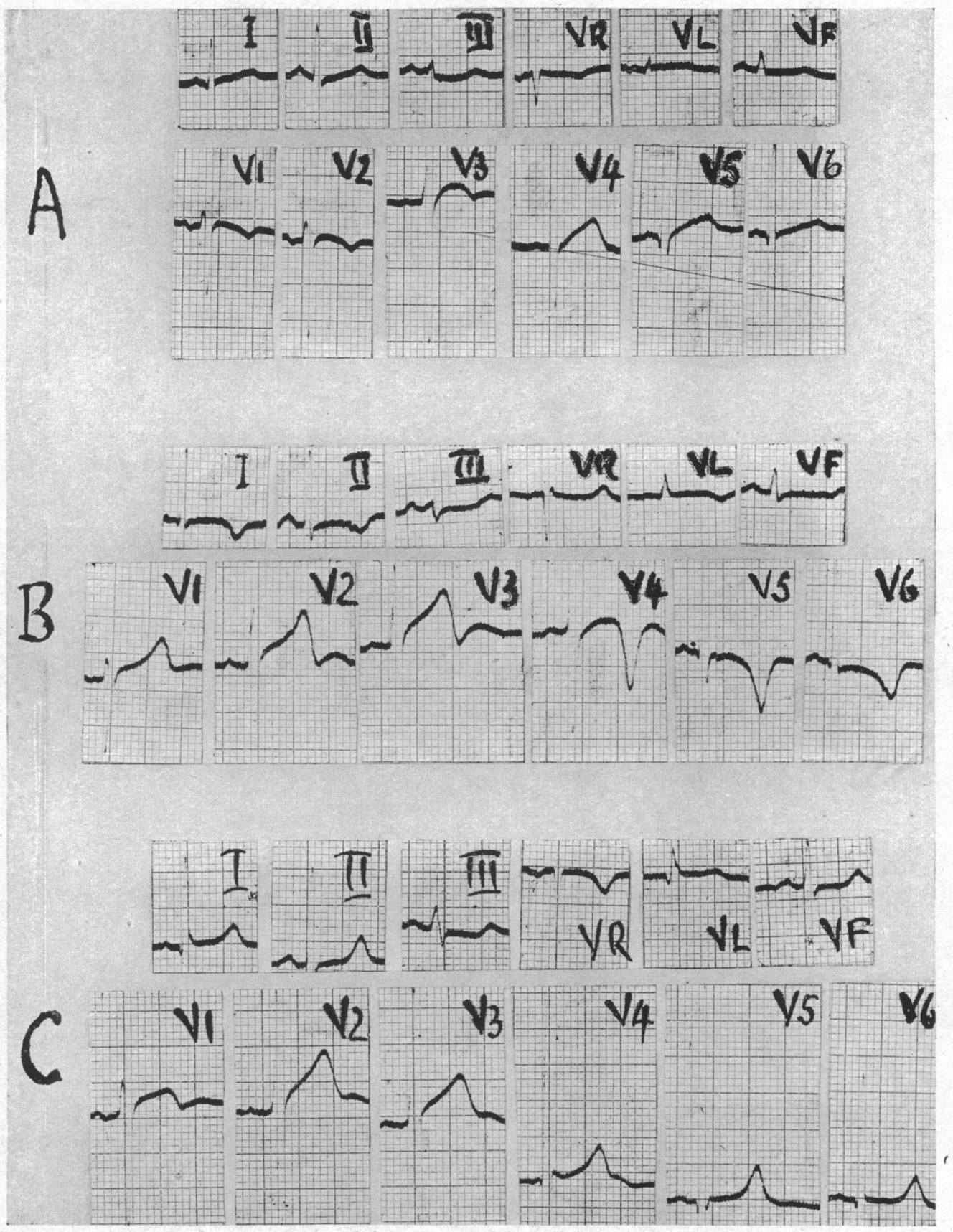

Fig. 3.-Serial electrocardiograms from patient referred to in legend to Fig. 2. Shows successive RS-T and T changes similar to those of subepicardial injury. Further discussion in text.

$\begin{array}{lll}\text { (A) } 5 / 4 / 49 \text {. (B) } 25 / 4 / 49 & \text { (C) } 8 / 7 / 49 \text {, when electrocardiogram first became stabilized. }\end{array}$ 


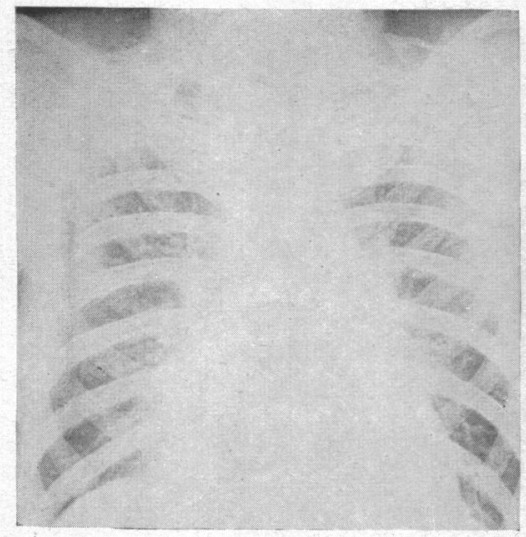

A

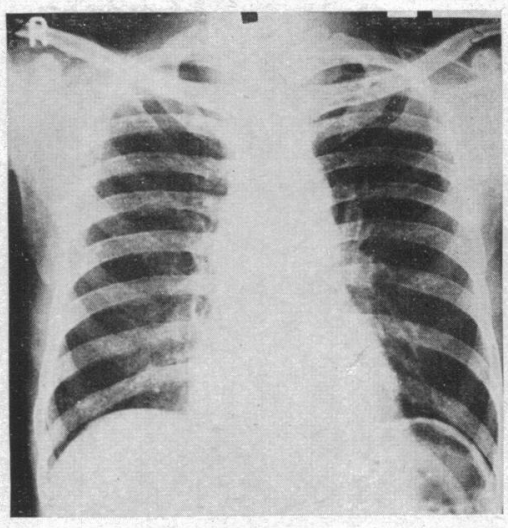

B

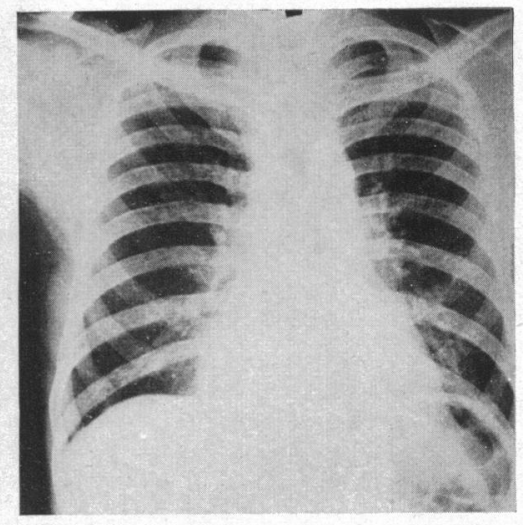

$\mathrm{C}$

FIG. 4.-Man, aged 51 (Reference No. A21980).

(A) As on admission, 27/6/49. Congestive heart failure.

(B) 12/7/49. Heart size now normal. Has received no treatment other than standard diet. No signs of congestive failure at this stage. Weight loss 50 pounds.

(C) $23 / 7 / 49$. Has been on restricted diet plus $25 \mathrm{mg}$. thiamin daily since $12 / 7 / 49$. Venous pressure now raised. Recurrence of œdema. Increase in heart size.

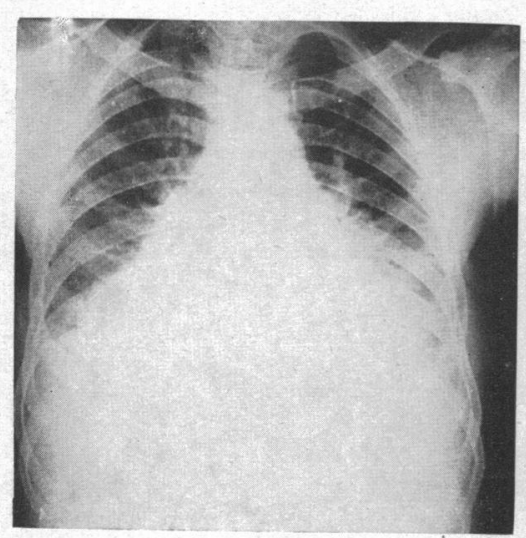

A

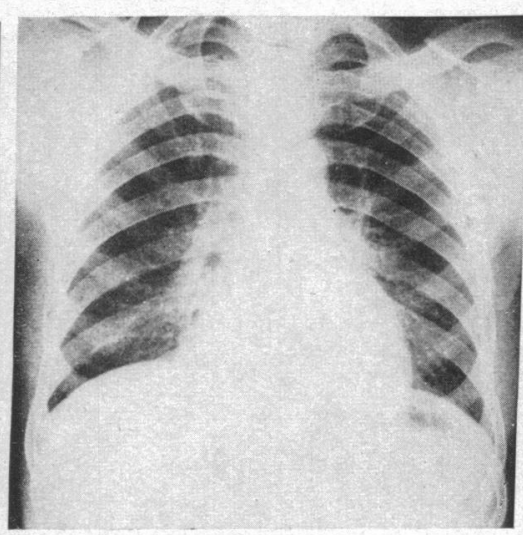

B

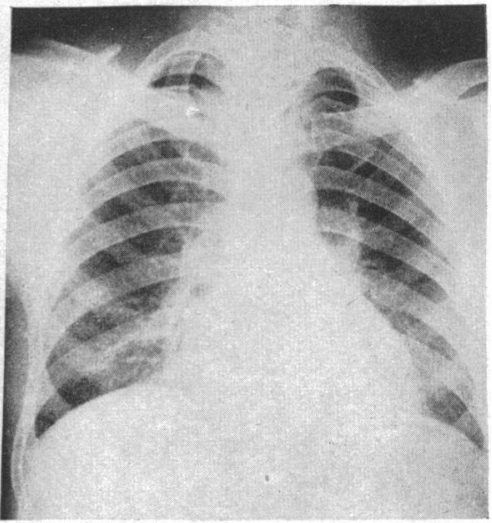

C

Fig. 5.-Man, aged 31 (Reference No. A13677)

(A) As on admission, 21/4/49. Congestive heart failure.

(B) 3/5/49. Has been on standard hospital diet since 21/4/49. No systemic venous engorgement or œdema at this stage. Slight residual enlargement of heart which persisted subsequently.

(C) 21/6/49. Has been on restricted diet plus 10 grams of brewers' yeast daily since 10/6/49, when heart size was as in (B). Increase in heart size now apparent. At same time neck veins were engorged and oedema had reappeared over sacrum.

Corresponding electrocardiograms are shown in Fig. 6.

(e) Five patients were given $15 \mathrm{~g}$. of brewers' yeast for 2-3 weeks without apparent benefit.

$(f)$ Nine patients took 500-800 mg. of alpha-tocopherol daily for a period of not less than three weeks. Their clinical condition was unaffected.

$(g)$ Three patients received $25 \mathrm{mg}$. of testosterone propionate daily for approximately 3 weeks without any beneficial effect.

These results show that when heart failure of this kind is not reversible by a wholesome diet alone no single drug or accessory food factor has yet been found substantially to augment the therapeutic value of that diet. Nor is there any evidence that curtailment of salt intake to an irreducible minimum does so. 


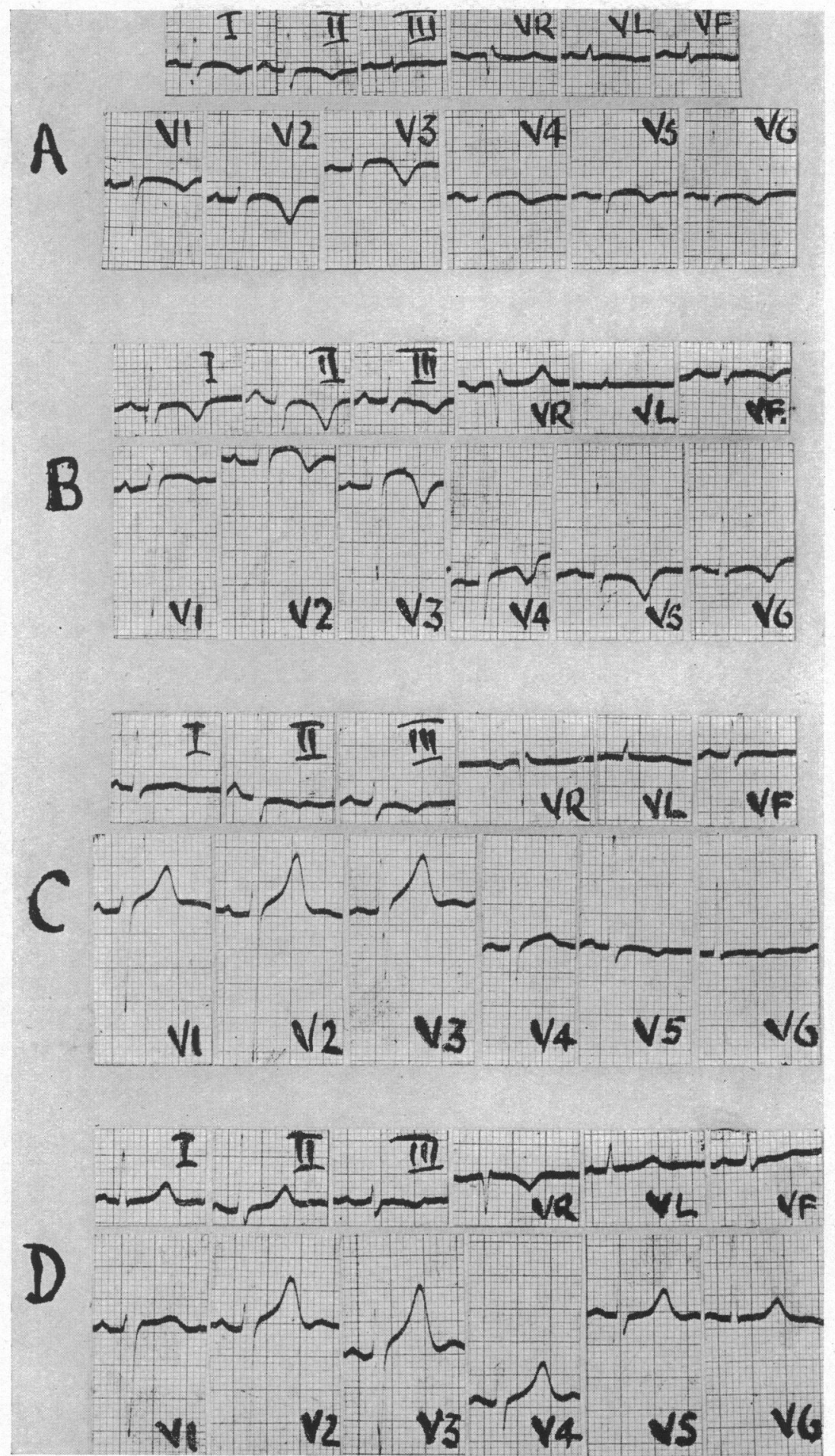

Fig. 6.-Serial electrocardiograms from same patient as referred to in legend to Fig. 5. The successive RS-T and T changes form the commonest cardiographic pattern in this form of heart failure. Further discussion in text.
(A) $21 / 4 / 49$.
(B) $4 / 5 / 49$.
(C) $22 / 6 / 49$
(D) $1 / 8 / 49$. 
The eight patients who ultimately died were also treated with digitalis, mersalyl, aneurin, and alpha-tocopherol, either singly or in various combinations, without avail. Even so it would be premature to conclude that none of these drugs can in any circumstances be beneficial. Current studies are designed to discover the detailed effects of digitalis (and other drugs) on circulatory dynamics in this disease.

A further continuation of the dietetic experiments mentioned above is involuntarily provided by the patients' return to their own homes and habits. The results, however, are more difficult to assess because these people tend to migrate, especially after illness, and because most are still unwilling to return to hospital except when totally disabled. Of the twenty-two who were dis-

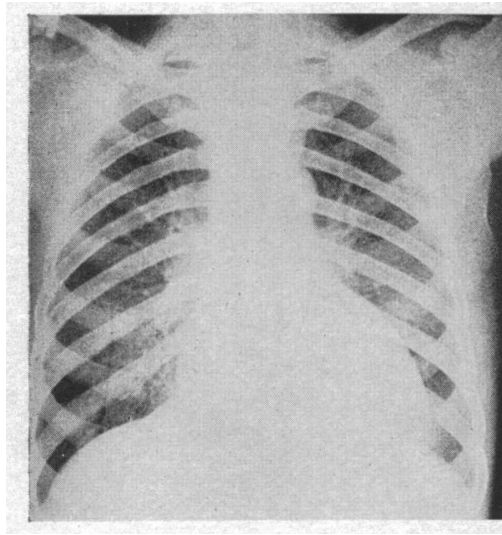

A

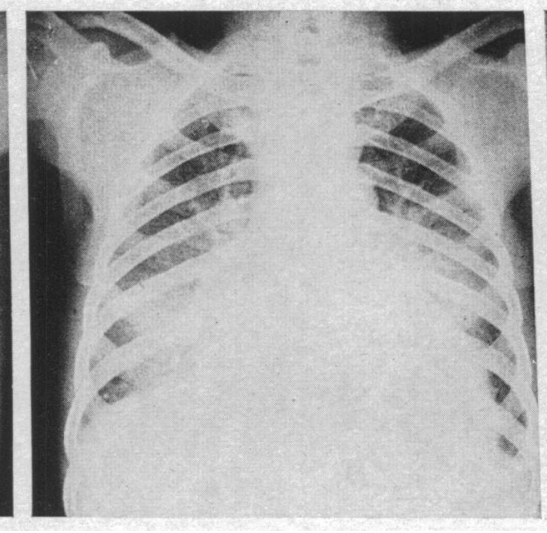

B

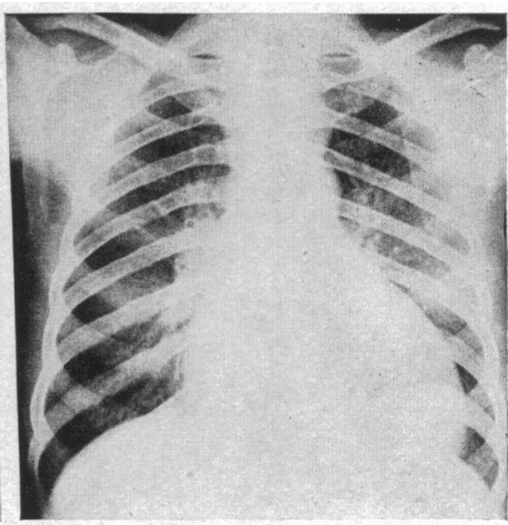

C

Fig. 7.-Man, aged 47 (Reference No. A19536).

(A) As on discharge from another institution on 14/6/49. Had been treated for congestive heart failure with digitalis, mercurial diuretics and ammonium chloride. Described as having recovered from congestive failure but heart remained enlarged.

(B) As on admission to this hospital on 29/6/49. Further enlargement of heart. Congestive failure.

(C) 15/7/49. Has received no treatment other than standard diet. Diminution in heart size. Venous pressure has fallen but not yet normal. Slight residual œdema although weight loss 35 pounds. No further improvement obtained by digitalization, mercurial diuretics, aneurin or alpha tocopherol.

charged from hospital, twelve were traced subsequently. All had relapsed or, where recovery had not been complete, deteriorated. Among these the longest possible period of time that could have elapsed between discharge and increase in heart size, was eight weeks; between discharge and congestive heart failure or obvious deterioration, if recovery had not been complete, twelve weeks. Seven were re-admitted to hospital as emergencies in gross congestive failure, three of these within four weeks of discharge (Fig. 7 and 8). So far as was possible in the circumstances it could not be established that any of the drugs previously mentioned had any prophylactic value. An exception may be mersalyl. Three patients who had some œdema when discharged were prevailed upon to attend the out-patient department twice weekly for injections of this drug. In these it appeared that œdema increased less rapidly and by a less degree than in the remainder, but the drug did not prevent enlargement of the heart nor progressive increase in peripheral venous pressure.

\section{Details of Progress under Treatment}

So far as the cardiovascular system was concerned patients were classifiable into four grades according to their response to all treatment so far adopted.

(1) Where progress was optimum, as it was in nine patients, the most striking sign of recovery was an increase in the amplitude of cardiac pulsation as observed fluoroscopically. This was commonly seen in four to five days, invariably in the first week, and preceded apparent diminution in heart size. After a week or ten days the heart size was obviously smaller and in two to four weeks 


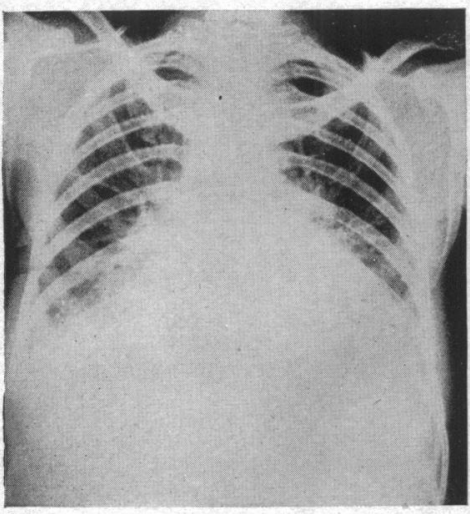

A

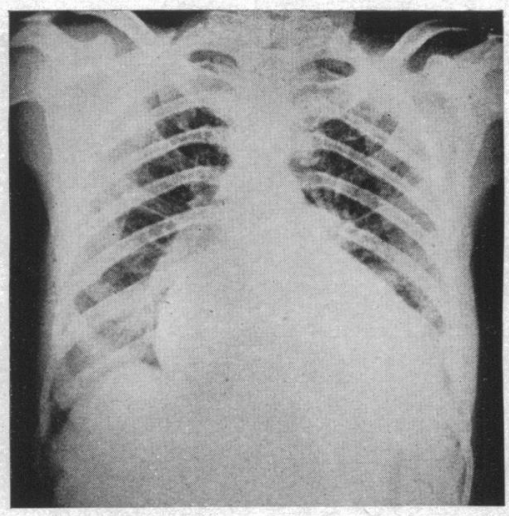

B

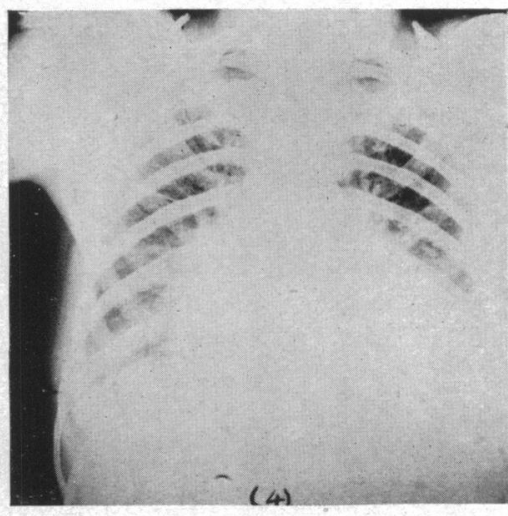

$\mathrm{C}$

Fig. 8.-Woman, aged 40 (Reference No. A2489).

(A) As on admission, 18/1/49. Congestive heart failure.

(B) 16/4/49. Maximum improvement since admission. Heart still greatly enlarged. At this time peripheral venous pressure was still raised and there was slight sacral œdema. This amount of improvement was obtained with dietetic treatment alone. Subsequently, digitalis, mersalyl, alpha-tocopherol, aneurin, and vitamin B complex, given singly or in appropriate combination, added nothing to this. The absence of significant pericardial effusion was confirmed by needling on three separate occasions. Patient discharged 30/4/39.

(C) Re-admission in congestive failure 15 days later.

normal (Fig. 1, 2, and 4). Gallop rhythm disappeared and the veins of the neck ceased to be engorged. Frequently in the phase of recovery there was a transient sinus bradycardia and an increase in systolic and diastolic pressures (Table III). These became stabilized at normal levels when recovery was complete. Urinary output increased, usually on the third or fourth day, and remained at a high level until the œdema subsided. The urinary excretion of chlorides increased at the same time. Weight loss in these circumstances varied in the nine patients from 34 to 62 pounds. Peritoneal and pleural effusions resolved less rapidly than subcutaneous œdema; sometimes they were aspirated to alleviate distress. Hydrarthroses subsided spontaneously in all instances before ascites or hydrothorax when these existed together; so did hydroceles. In two patients with bilateral hydrocele one side was aspirated and the other left untouched except for removal of $5 \mathrm{ml}$. of fluid for examination. The aspirated hydrocele did not recur in appreciable amount and the other subsided spontaneously at the same time as the anasarca. The protein content of hydrocele fluid from both sides was similar in each of these patients.

Probably the best guide to the total disappearance of ædema was a gain in weight following its precipitous decline. This was invariable. After this stage most patients continued to increase in weight during the remainder of the time that they were in hospital.

(2) Patients in the second grade were similar in so far as œdema disappeared but the heart remained slightly enlarged (Fig. 5 and 7). There were seven in this category and three of these had a permanently raised venous pressure. In two gallop rhythm persisted.

(3) Eight patients improved in every way but they failed to become œdema-free and their heart size, though substantially diminished, did not revert to normal (Fig. 8). Gallop rhythm persisted and peripheral venous pressure continued to be raised. It is equally characteristic of the second and third grades as of the first that arterial pressures rose temporarily during the phase of clinical improvement.

(4) In nine patients the circulatory failure was in all respects irreversible. They were gravely ill on admission but lived on for weeks or even months (and two still do) in a water-logged condition. The heart in all of these was enormous and virtually motionless when viewed fluoroscopically (Fig. 9). The œdematous tissues were indurated and pitted on pressure to a small extent only. It was confirmed at necropsy in six patients that this was due to cutaneous and subcutaneous fibrosis. 
This was not confined to the most advanced stage of the disease for the same change, though in less degree, was demonstrated by biopsy in two patients from the third grade.

In all patients, including those who made a complete recovery from congestive heart failure, the liver remained enlarged, in most instances grossly so. The diminution in the size of the liver with subsidence of congestion was trivial; the recession of its lower border did not in any instance exceed $2 \mathrm{~cm}$. The pain of liver distension, which was a prominent initial symptom, disappeared rapidly in all who improved, and from that time the palpable edge was hard, uniform and free from tenderness.

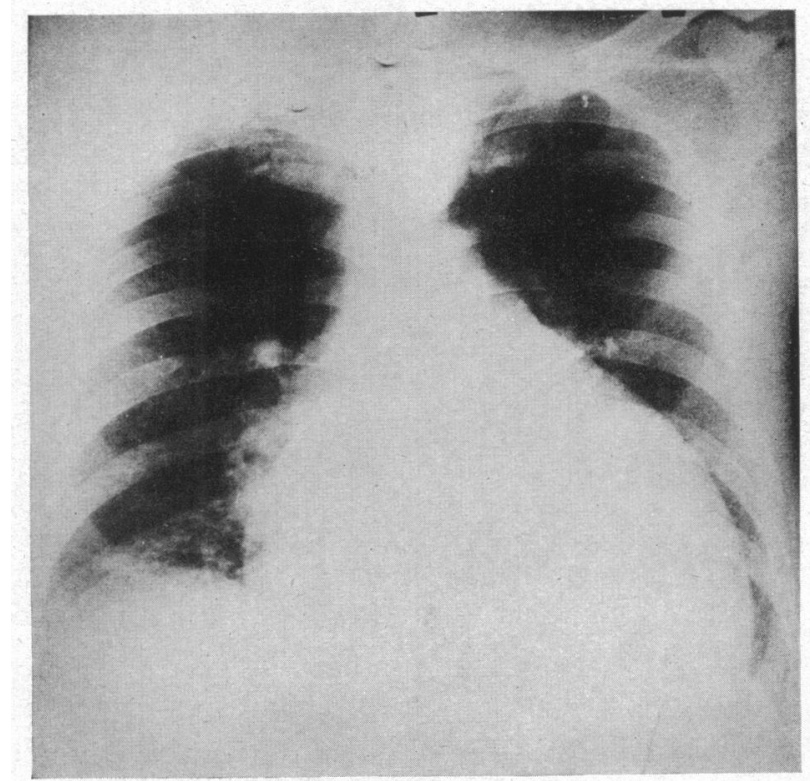

FIG. 9.-Man, aged 50 (Reference No. A295). Teleradiogram showing gross enlargement of whole heart; clear lung fields. Patient had advanced right heart failure, resistent to all forms of treatment. Pericardium was needled but no fluid located. Died subsequently with pulmonary congestion and odema. Corresponding electrocardiogram shown in Fig. 10.

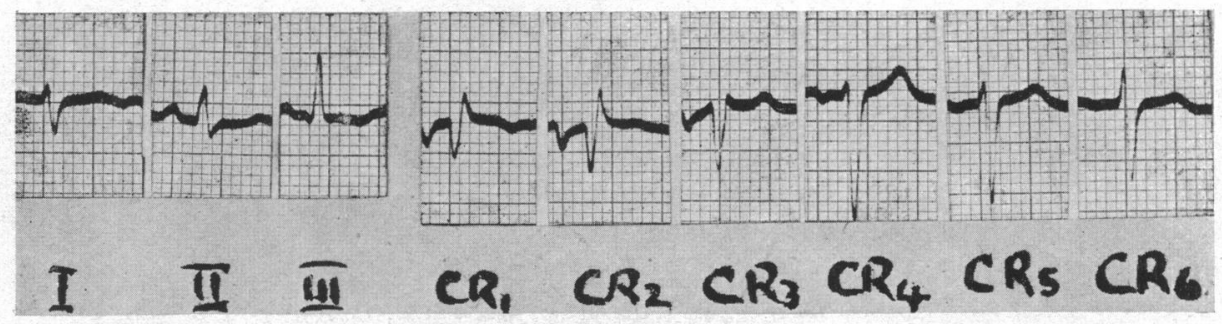

Fig. 10.-Electrocardiogram from patient referred to in legend to Fig. 9. At subsequent necropsy heart was found to weigh 750 grams. There was hypertrophy of both ventricles, chiefly of the right.

Statistically, plasma albumen and total protein (estimated per $100 \mathrm{ml}$. of plasma) increased during the time that patients were in hospital (Table IV). In the individual patient this increase did not correlate with the degree of improvement. The variation in plasma globulin during the same time was not significant but the trend of globulin values also was towards a higher level. It was usual for sensory loss to diminish and motor power to improve but deep reflexes were not restored. The only patient who had severe motor loss still had bilateral drop foot when discharged 
four months later. He had prolonged treatment with aneurin but it could not be established that this vitamin had specific curative value (it did appear to stimulate appetite).

While in hospital eight patients developed sudden chest pain followed by hæmoptysis, presumably due to pulmonary embolism, which was not fatal in any instance. In two only was there radiological evidence of infarction and these had pulmonary congestion. In no case was there convincing evidence of peripheral venous thrombosis. Post-mortem findings in other patients indicated that the source of the embolus was ventricular mural thrombosis. Arterial embolism in one or more limbs occurred in three patients.

\section{Mortality AND Mode of Death}

In this group of 30 patients eight died. One patient, after slow deterioration, died in apparent peripheral circulatory collapse. One, already seriously ill, died from massive pulmonary embolism which had its origin in a mural thrombus (this patient is not included in the previous reference to pulmonary embolism). Another patient, a middle-aged woman, after a most striking improvement, suddenly dropped down dead while sitting in a chair conversing amiably with her neighbour; the cause of this was not apparent at necropsy. Four died from progressive failure of the whole heart; a fifth in the same category was moribund on admission.

Notwithstanding the high mortality a more striking feature of this disease is the relatively long time that patients with enormous hearts and gross anasarca may live and even be ambulatory. It is characteristic of members of the Bantu race in this locality that they do not arrive in hospital before their disease is advanced in the extreme. With the single exception of the patient who died so unexpectedly after progressing so well, all who died had previously been in hospital on account of similar symptoms and were, when ultimately re-admitted, in chronic and (so far as is now known) irreversible heart failure.

\section{PATHOLOGY}

Necropsy. Post-mortem examinations were done on all patients who died but it is now realized that these were not sufficiently comprehensive to reveal the complex pathology of this disease. For that reason and because a detailed study of post-mortem material is now being undertaken a full account of the pathological anatomy will not be attempted at this stage.

In all instances the heart was greatly enlarged and its weight excessive; the walls of both ventricles were thickened. The heart valves were intact, the coronary arterial system and aorta not diseased. No convincing evidence of subendocardial necrosis or fibrosis was found in any (Bedford and Konstam, 1946; Davies, 1948). The amount of pericardial fluid was not significant from the point of view of producing either the clinical syndrome or the radiological appearance of the heart. Microscopically, there was inter-fibrillary cedema of the myocardium but no " hydropic" degeneration. Hypertrophy of muscle fibres in both ventricles was usual. Suitably stained sections showed minimal interstitial fibrosis.

The liver was enlarged in all and, though congested, fairly firm in consistency. In three patients it was obviously cirrhotic but in these, unfortunately, microscopic examination was omitted. In the remainder the histological features were those of hæmochromatosis (pigmentary cirrhosis or cytosiderosis with cirrhosis of Gillman and Gillman, 1945). In some instances (it was not looked for in all) the same change affected other organs such as the pancreas and spleen, but not the heart.

The lungs of all were congested but without primary disease. Pulmonary infarction was found in one patient and splenic infarction in another. In these, ante-mortem thrombus was adherent to the endocardial surface of the right and left ventricle respectively. Nephrosclerosis was excluded in all.

Liver biopsy. Needle liver biopsy was done on all patients who survived (22). This minor operation was undertaken only after maximum recovery from congestive failure. No untoward effect occurred in any case. Apart from chronic venous congestion and its sequelæ, which were observed 
in four specimens, all biopsy sections showed disease of the liver. In nineteen the salient lesion was cytosiderosis (Fig. 11). Of ten in which the siderosis was both intra- and extra-cellular there was portal fibrosis in seven; of nine in which it was intra-cellular only there was portal fibrosis in four. In three patients the only lesion revealed by biopsy was fatty change. In eleven this co-existed with hæmochromatosis. Round cell infiltration of the portal tracts was a common accompaniment of the other lesions mentioned.

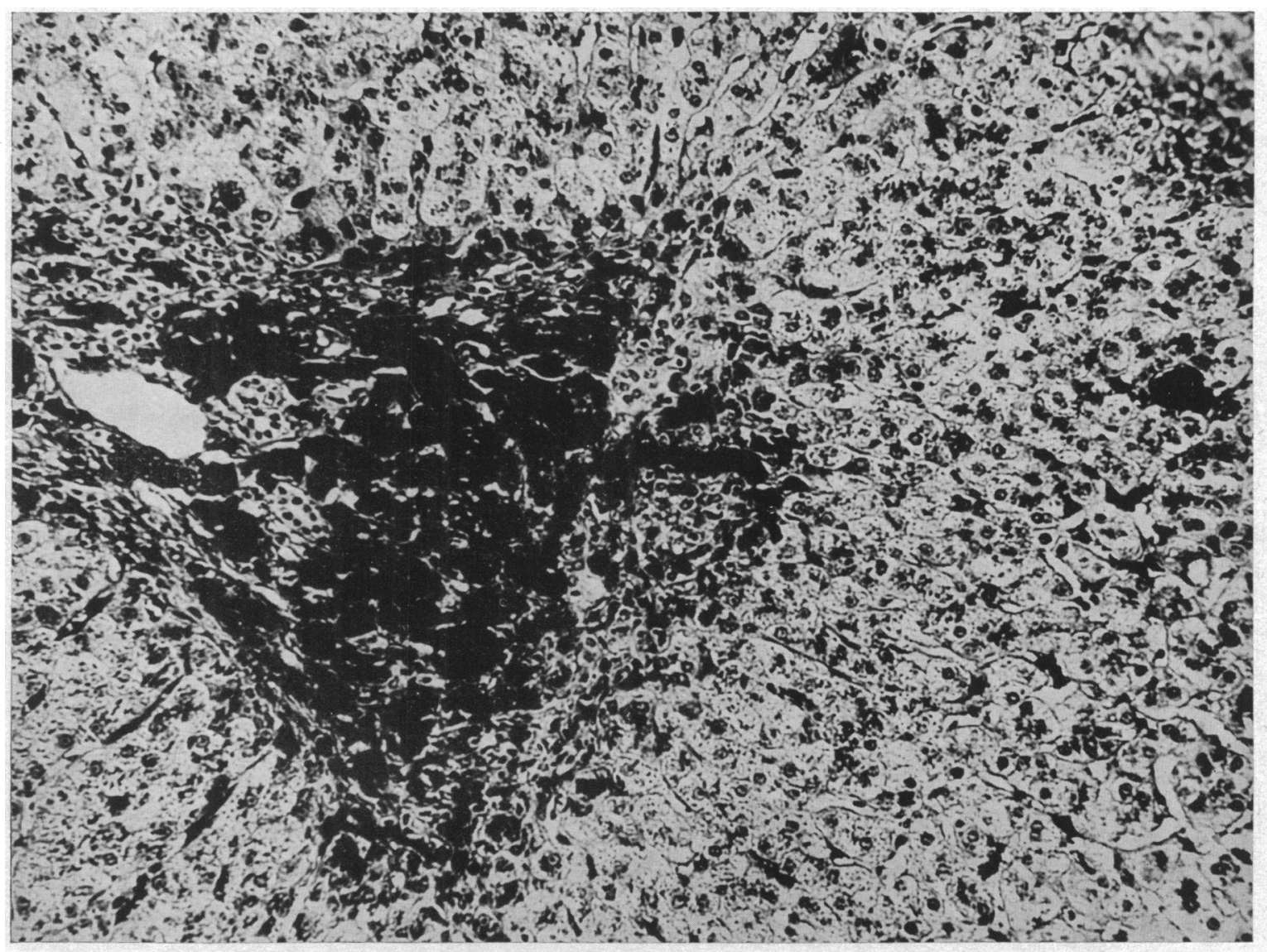

Fig. 11.-Man, aged 34 (Reference No. 16434/48). Cf. Fig. 1, which refers to same patient: Needle biopsy of liver showing portal fibrosis and round cell infiltration. There is also deposition of hæmosiderin which is visible not only in the liver cells but as a very heavy deposit in the portal tract and in the Kupffer cells of the sinusoids. $H \& \mathrm{E}$ and Prussian Blue reaction. $\times 210$.

\section{Discussion}

The syndrome of adema. Irrespective of the detailed mechanism, congestive heart failure constitutes a valid cause of œdema. Nevertheless, the œdema that has been described differs in some respects from cardiac œdema. In degree it was, almost without exception, extreme. Its distribution on the body surface was generalized. More than 40 per cent of all patients had hydrarthroses and 20 per cent had bilateral hydrocele. That in individual patients these effusions behaved in the same way as the effusions known to be dropsical suggests that they had a common cause. The protein content of the joint and hydrocele fluids was compatible with this interpretation. Notwithstanding its widespread distribution, however, the œedema was always greater in the dependent parts of the body than elsewhere. As the œdema subsided it first disappeared from the face and lastly (in the 
recumbent patient) from the soft tissues overlying the sacrum. The accumulation of odema, according to Burch and Winsor (1944), is restrained by the elasticity of the skin. It is no doubt true, although it has not been proven in this group of patients, that poor nutrition causes a diminution of tissue elasticity.

Malnutrition and disease of the liver are both potential causes of œdema. In each case the protein content of the odema fluid is substantially less than it is in œedema of cardiac origin (Peters and Van Slyke, 1932; Bodansky and Bodansky, 1944). It will presently be argued that, in the patients now under discussion, chronic malnutrition was the cause of heart failure; liver disease was shown to co-exist in every instance. Yet the protein content of odema fluid from the various body cavities and subcutaneous tissues, estimated admittedly in only a small number of patients, did not differ significantly from that reported elsewhere in congestive heart failure of other ætiology (Gilligan, et al., 1934; Bramkamp, 1935; Fishberg, 1940). Only in three patients were plasma albumen levels less than $3.0 \mathrm{~g}$. per $100 \mathrm{ml}$., the reputed "critical level" for nutritional œedema (Bruckman and Peters, 1930). It is unusual for ascites to develop in hepatic disease unless the serum albumen falls below $2.5 \mathrm{~g}$. per $100 \mathrm{ml}$. (Higgins et al., 1947). In the present series albumen levels less than this were recorded in two patients only, yet ascites was clinically apparent in twentyseven. Neither plasma albumen nor total protein values correlated with the degree of odema preceding treatment nor with the residual œdema where recovery was incomplete. According to Starling's concept of a balance between the oncotic pressure of the plasma and the hydrostatic pressure of the blood in the capillaries (Starling, 1896) any reduction in plasma protein, especially in the albumen fraction, will tend to cause an accumulation of fluid in the tissue spaces. Apart from that there is, in the present instance, no positive evidence that hypoproteinæmia played a greater role in the genesis of odema than it does in congestive heart failure of other kind (Payne and Peters, 1932). It would be helpful in this respect to know the circulating blood volume. This is said to be increased in all forms of congestive heart failure, largely by reason of an increase in corpuscular volume. (Meneely, and Kaltreider, 1943). Hæmatocrit readings in our patients were too few to permit of reliable comment but hæmoglobin (and r.b.c.) values were strikingly normal. These, however, were recorded once only, when the patient first came under observation. Levels of plasma albumen and also of plasma globulin rose over the period of clinical improvement. It may well be that this reflects a falling blood volume during recovery from congestive failure.

Comment on differential diagnosis. Because this disease has frequently been labelled hypertensive heart failure in the past, care has been taken to exclude any with established hypertension from the series now reported. Systolic and diastolic pressures did increase in most patients in the phase of recovery but these pressures subsequently returned to normal levels. Furthermore, although there is good reason to believe that heart failure of other ætiology is frequently precipitated by malnutrition, and the pattern of failure modified by it, all with any other potential cause of heart failure were excluded. Notwithstanding the wide range of plasma cholesterol there was no evidence of thyroid disease in any instance. The basal metabolic rate, recorded in those patients in whom plasma cholesterol deviated most from the mean, bore no relation to the cholesterol level. The mean plasma cholesterol was low. So far as a single recording has any significance this may be an index of chronic malnutrition (Man and Gildea, 1936) or liver failure (Peters and Van Slyke, 1946). Of greater import in this respect is the fasting hypoglycæmia, a known accompaniment of advanced hepatic disease (Judd et al., 1934; Moore et al., 1934; Conn et al., 1938). The syndrome that is now reported cannot be identified with Van Gierke's disease but glycogen metabolism has yet to be studied in detail. No significance could be attached to serum potassium levels in determining the pattern of the electrocardiogram.

Etiology. Recent surveys have disclosed the prevalence of malnutrition in the non-European community of this country (Fox, 1934, 1939; Brock and Latsky, 1944; Dugard, 1945). Gillman and Gillman (1945) have shown that in the malnutritional syndrome of these people liver disease is invariable; fatty infiltration, cytosiderosis, and cirrhosis, though not necessarily consecutive lesions, are patterns of liver reaction to the injury of prolonged malnutrition. They distinguish two 
phases of cytosiderosis. In the first phase iron pigment appears in the liver cells and little or none in the Kupffer cells; in the second iron is additionally deposited in the Kupffer cells and portal tracts (Gillman and Gillman, 1947). Cirrhosis and fatty change, or either alone, may co-exist in either phase. All patients now reported had liver disease of this kind; all stages of the disease were manifest. The comprehensive histological diagnosis in most instances was pigmentary cịrrhosis that is indistinguishable from hæmochromatosis.

Because people known to be malnourished develop heart failure that otherwise cannot be explained, it does not follow that malnutrition is the cause. Nor does this necessarily follow because they recover when given an adequate diet at the same time as they are confined to bed in hospital. But the development, under the same controlled conditions, of cardiac enlargement and failure when the diet is restricted to the patients' accustomed fare (albeit that this observation was not frequently repeated) is strong evidence that the deficient diet and not some positive environmental factor is immediately responsible. Gillman (1944), in his investigation of nutritional liver injury, fed rats on a diet comparable to that of the South African Bantu. The rats developed fatty infiltration of the liver which in many instances progressed to cirrhosis. It is noteworthy that these rats' hearts became greatly enlarged.

The hepatic lesion that has been shown, without exception in the present investigation, to accompany cardiovascular disease is irreversible. In contrast, cardiac enlargement and failure, of moderate or even severe degree, are reversible-under the influence of wholesome food alone. There is a distressingly high incidence of malignant malnutrition (kwashiorkor) among Bantu children; in that syndrome the liver is always fatty (Gillman et al., 1944; Altmann, 1948). The diet of the patients now described has been deficient from the time that they were weaned. The presumption is that the syndrome portrayed in the adult dates from childhood.

It is indisputable that for a long time the heart remains functionally intact despite deficient diet. Its ultimate failure is understandable as a cumulative effect of prolonged malnutrition. On the analogy of other nutritional diseases the ready recovery from congestive failure and the diminution in heart size when the dietary deficiency is made good substantiates this interpretation. What is less easily understood in these circumstances is the rapidity with which heart failure recurs in the successfully treated patient when his diet is again restricted. Clearly the heart has become "sensitized " in some way to the influence of inadequate food intake. It may be that a salutary role in the nutrition of the heart is exercised by the liver; that the heart fails when the liver, because of its own progressive injury, can no longer function in this way.

Isolated deficiencies. Gynæcomastia, which is an index of malnutrition in the African, is reputed to be due to failure by the liver to inactivate œstrogens (Davies, 1949). It was the frequency of this and other signs of feminization that prompted the use of testosterone as a therapeutic agent. It had no beneficial effect. In the experimental animal tocopherol deficiency causes (among other things) degenerative changes in the testes and myocardium (Mason, 1926; Mason and Emmel, 1945); progressive cardiographic abnormalities have been reported by Gullickson and Calverley (1946). Tocopherol protects the animal liver against the injurious effects of a diet deficient in thioamino acids (Schwarz, 1944). These facts constitute the rationale for the therapeutic trial of alpha tocopherol. Strikingly favourable results in the treatment of cardiovascular disease with this vitamin have been reported by Vogelsang, Shute and Shute (1948) but no benefit accrued to any of our patients treated in this way. Apart from the association of aneurin deficiency with cardiovascular failure (Follis et al., 1943) it is of interest that three of four dogs rendered pyridoxine-deficient by Street, Cowgill and Zimmerman (1941) developed signs of congestive heart failure and died suddenly. Neither aneurin nor whole vitamin B had any curative or prophylactic value in the type of heart failure now under discussion.

Inanition alone, as distinct from qualitative defects of diet, causes some change in most organs. Although these have no specificity they are continually being attributed to deficiencies of single nutrients (Follis, 1948). Notwithstanding the absence of vitamins from the Bantu diet the classical avitaminoses are rare. 
It may be that deficiency of a single food factor is the cause of heart disease in the South African Bantu. Investigation of this possibility is being continued; at present, attention is being directed to the essential amino acids that are lacking from maize protein. Nevertheless, less emphasis should be laid on the ultimate components of diet than on the provision of wholesome table food.

\section{SUMMARY}

A form of congestive heart failure, believed not to have been previously described, that occurs in African adults, has been observed. The clinical syndrome and the ætiology of the condition have been studied in 30 cases.

Apart from the common signs of congestive failure outstanding clinical features were (a) enlargement of the whole heart which, on fluoroscopy, was typically inert, $(b)$ the constancy of gallop rhythm, $(c)$ the extreme degree of œdema, and $(d)$ the co-existence of disease of the liver.

The diet of all patients was, quantitatively and qualitatively, deficient. In five patients who willingly subjected themselves to the trial it was shown that once heart failure of this kind had developed it progressed, even under optimum environmental conditions, so long as they continued to subsist on their accustomed diet. .

In all but the most advanced stages of the disease heart size diminished and signs of failure retrogressed when a well balanced diet was substituted for the deficient one. Not only did the disease relapse when patients left hospital and reverted, inevitably, to their previous diet, but cardiac enlargement and failure readily developed in six convalescent patients under controlled conditions when their diet was restricted to their habitual fare.

When the disease has been long established enlargement of the heart and congestive failure become irreversible.

No drug or single food factor has been found to augment the curative value of wholesome food or to have any prophylactic or therapeutic value in face of the deficient diet on which these people have to live. Mercurial diuretics may be useful in controlling œedema in the more chronic phase of the disease. Aneurin is no exception to this statement.

This syndrome of heart failure does not clinically resemble that due to beri-beri, and there are none of the features of a hyperkinetic circulation.

In the African, fatty infiltration of the liver, which may be fatal or progress to cytosiderosis or cirrhosis or both, is caused by prolonged underfeeding on a diet identical with that of the patients discussed in this paper. One or other variant of this liver lesion was found in all cases.

For a long time, notwithstanding deficient diet and progressive liver injury, the heart remains free from gross disease. When the heart has once failed and recovered under treatment, it will readily fail again under the influence of the same deficient diet, even though recovery had seemed complete. It may be that in circumstances of continued underfeeding, a function of the liver is to ensure optimum nutrition of the heart; that ultimate failure of the heart, although a consequence of malnutrition, may be conditioned by primary failure of the liver.

I wish to thank Dr. J. F. Murray for the histological work in this investigation, Dr. R. Cassel and Mr. H. D. Barnes for the biochemical analyses, and Mr. A. M. Shevitz for the photographs of X-ray films. I am grateful to Dr. J. C. Gilroy and Dr. L. H. Horwitz for placing at my disposal four of the cases that are included in this report.

\section{REFERENCES}

Alsmeer, W. C., and Wenckebach, K. F. (1929). Wien. Arch. inn. Med., 16, 193.

Altmann, A. (1948). Clin. Proc., 7, 32.

Bain, C. W. C., and Redfern, E. McV. (1948). Brit. Heart J., 10, 9.

Bedford, D. E., and Konstam, G. L. (1946). Ibid., 8, 236.

Blair, M. R. (1947). Race Relations (Journal of the South African Institute of Race Relations), $14,159$.

Blankenhorn, M. A. (1945). Ann. intern. Med., 23, 398. 
Bodansky, M., and Bodansky, O. (1940). Biochemistry of Disease. The Macmillan Company, New York. Bramkamp, R. G. (1935). J. clin. Invest., 14, 34.

Brock, J. F., and Latsky, J. M. (1942). S. Afr. med. J., 16, 255.

Bruckman, F. S., and Peters, J. P. (1930). J. clin. Invest., 8, 591.

Burch, G. E., and'Winsor, T. (1944). J. Amer. med. Ass., 126, 163.

Cecil, R. L. (1947). A Textbook of Medicine. W. B. Saunders Company, Philadelphia.

Conn, J. W., Newburgh, L. H., Johnston, M. W., and Sheldon, J. M. (1938), Arch. intern. Med., $62,765$.

Davies, J. N. P. (1948a). E. Afr. med. J., 25, 10 and 454. (1948b). Lancet, 1, 317.

(1949). Brit. med. J., 2, 677.

Dock, W. (1940). Trans. Ass. Amer. Phys., 15, 61.

Dugard, J. H. (1945). S. Afr. med. J., 19, 412.

Fishberg, A. M. (1940). Heart Failure. Lea and Febisher, Philadelphia.

Follis, R. H. (1948). The Pathology of Nutritional Disease. Charles C. Thomas, Springfield, Ill. , Miller, M. H., Wintrobe, M. M., and Stein, H. J. (1943). Amer. J. Path., 19, 341.

Fox, F. W. (1934).' S. Afr. med. J., 8, 3. (1939). Ibid., 13, 87.

- (1941). Appendix 1 to A Study of African Income and Expenditure in 987 Families in Johannesburg, by Janisch, M. City of Johannesburg Non-European Affairs Department.

Gilligan, D. R., Volk, M. C., and Blumgart, H. L. (1934). J. clin. Invest., 13, 365.

Gillman, J. (1944). Brit. med. J., 1, 149.

-, and Gillman, T. (1945). Archiv. Path., 40, 239.

- - - (1947). Gastroenterology, 8, 19.

Go, Hammer, E., Inglis, J., and Friedlander, J. (1944). Nature, London, 154, 148.

Goldberger, E. (1947). Unipolar Lead Electrocardiography. Henry Kimpton, London.

Gullickson, T. W., and Calverley, C. E. (1946). Science, 104, 312.

Harrison, G. A. (1947). Chemical Methods in Clinical Medicine. Churchill, London.

Higgins, G., Kelsall, A. R., O'Brien, J. R. P., Stewart, A. M., and Witts, L. J. (1947). Quart. J. Med., N.S., 16, 263.

Hussey, H. H., and Katz, S. (1942). Med. Ann. Distr. Columbia, 11, 247.

Judd, E. S., Kepler, E. J., and Rynearson, E. H. (1934). Amer. J. Surg., 24, 345.

Lurie, H. I. (1949). Personal communication.

Man, E. B., and Gildea, E. F. (1936). J. clin. Invest., 15, 203.

Mason, K. E. (1926). J. exp. Zool., 45, 159.

, and Emmel, A. F. (1945). Anat. Rec., 92, 33.

Meneely, G. R., and Kaltreider, N. L. (1943). J. clin. Invest., 22, 521.

Moore, H., O'Farrell, W. R., and Headon, M. F. (1934). Brit. med. J., 1, 225.

Moore, N. S., and Van Slyke, D. D. (1930). J. clin. Invest., 8, 337.

Payne, S. A., and Peters, J. P. (1932). Ibid., 11, 103.

Peters, J. P., and Van Slyke, D. D. (1946). Quantitative Clinical Chemistry, vol. 1. Williams and Wilkins Company, Baltimore.

Phillips, R. E. (1938). The Bantu in the City. Lovedale Press, Cape Province.

Schwarz, K. (1944). Hoppe-Seyl. Z., 281, 109.

Starling, E. H. (1896). J. Physiol., 19, 312.

Street, H. R., Cowgill, G. R., and Zimmerman, M. H. (1941). J. Nutrit., 21, 275.

Sullivan, M., and Nicholls, J. (1940). J. invest. Dermat., 3, 337.

Trevorrow, V., Kaser, M., Patterson, J. P., and Hill, R. M. (1942). J. lab. clin. Med., 27, 471.

Vilter, C. F. (1945). Cincinn. J. Med., 26, 153.

Vogelsang, A., Shute, E., and Shute, W. (1948). Med. Rec., 161, 83.

Weiss, S., and Wilkins, R. W. (1936). Trans. Ass. Amer. Phys., 51, 341.

W, (1937). J. Amer. med. Ass., 109, 786.

Wenckebach, K. F. (1928). Lancet, 2, 265.

- (1932). Geneesk. Tijdschr. Ned.-Ind., 72, 915.

- (1934). Das Beriberi-Hertz. Julius Springer, Berlin. 